\title{
Mitigation of ammonia losses from urea applied to a pastoral system: The effect of nBTPT and timing and amount of irrigation
}

\author{
M. ZAMAN ${ }^{1}$, S. SAGGAR ${ }^{2}$ and A.D. STAFFORD ${ }^{1}$ \\ ${ }^{1}$ Ballance Agri-Nutrients Ltd, Private Bag 12503, Tauranga 3143, New Zealand \\ ${ }^{2}$ LandCare Research Private Bag 11052, Palmerston North.
}

mzaman@ballance.co.nz

\begin{abstract}
To investigate the effect of applying urea with or without the urease inhibitor (UI) N-(n-butyl) thiophosphoric triamide (nBTPT - trade name Agrotain ${ }^{\circledR}$ ) and to assess impact of the amount and timing of irrigation on subsequent ammonia $\left(\mathrm{NH}_{3}\right)$ emission, a field trial was set up on a research farm at Massey University, Palmerston North, New Zealand in December 2012. Measurements of the daily $\mathrm{NH}_{3}$ emission showed that majority of $\mathrm{NH}_{3}$ losses occurred during the first 1-3 days following urea application. Delaying irrigation for $48 \mathrm{hr}$ post urea application resulted in high average $\mathrm{NH}_{3}-\mathrm{N}$ losses, at $23 \%$ and $28.3 \%$ for urea applied at 30 and $60 \mathrm{~kg} \mathrm{~N} \mathrm{ha}^{-1}$, respectively. However, even when 5 or $10 \mathrm{~mm}$ of irrigation was applied 8 hours after urea application, average $\mathrm{NH}_{3}$ losses were still 11.3\% and $14.4 \%$ of the $\mathrm{N}$ applied at 30 and $60 \mathrm{~kg} \mathrm{~N} \mathrm{ha}^{-1}$, respectively. Our results suggest that 5 to $10 \mathrm{~mm}$ of irrigation/rainfall is needed very soon $(<8 \mathrm{hr})$ after urea application to supress $\mathrm{NH}_{3}$ volatilisation depending on initial soil moisture contents. If this rainfall/irrigation is not guaranteed, then $\mathrm{NH}_{3}$ losses associated with standard urea application can effectively be reduced by $47 \%$ using urea treated with $\mathrm{nBTPT}$.
\end{abstract}

Keywords Agrotain, ammonia losses, irrigation, nBTPT, urea, volatilisation

\section{Introduction}

For managed grasslands in New Zealand, the supply of nitrogen $(\mathrm{N})$ after every rotation of grazing is critical if enough pasture is to be grown to meet stock feed demand. In New Zealand's legume-based pastures, $\mathrm{N}$ application rates have traditionally been much lower because of $\mathrm{N}$ fixation by white clover (Ledgard et al. 1999). However, this state of affairs has changed dramatically in New Zealand with increasing intensification of grazing over the last 15 years (Statistics New Zealand 2012). In addition to maintenance phosphorus, sulphur and potassium, it is the supply of $\mathrm{N}$ that generally represents the greatest limitation to pasture growth because of (i) the nonuniform distribution of excreta- $\mathrm{N}$ in grazed pastures, and (ii) the fact that $\mathrm{N}$ released from mineralisation of soil organic $\mathrm{N}$ or organic wastes (farm dairy effluent, dairy pond sludge) cannot meet the pasture $\mathrm{N}$ demand (Zaman et al. 1998). Thus, applying chemical $\mathrm{N}$ fertiliser, predominantly urea, is necessary to maintain current levels of productivity. However, urea has been reported to have lower fertiliser use efficiency (FUE) relative to ammonium- and nitrate-based fertilisers (Zaman et al. 2008). This lower FUE also occurs if urea is applied in conditions of sub-optimal soil moisture or at too low or high a temperature. The reduction in efficiency is related to $\mathrm{N}$ losses via ammonia $\left(\mathrm{NH}_{3}\right)$ volatilisation. In New Zealand, the twin effects of rising fertiliser $\mathrm{N}$ prices, both domestic and international, and increasing environmental restrictions on fertiliser $\mathrm{N}$ use by regulatory authorities have led research scientists and companies to develop a variety of management practices and technologies to improve the FUE of urea. One such approach is to treat granular urea with the urease inhibitor (UI) N-(n-butyl) thiophosphoric triamide (nBTPT - trade-name Agrotain ${ }^{\circledR}$ ) which delays urea's hydrolysis by 7 to 10 days and thus significantly reduces $\mathrm{NH}_{3}$ losses (Zaman et al. 2008, 2013; Saggar et al. 2013).

Ammonia loss, a chemical process catalysed by the ubiquitous urease enzyme, can have negative effects on our wider ecosystem, and has been linked to agronomic losses on farm, soil acidification, poor atmospheric quality, nutrient-N enrichment of sensitive habitats and the eutrophication of surface water bodies, and health issues (Barthelmie \& Pryor 1998; Zaman et al. 2008; Sanz-Cobena et al. 2011).

Urea, when used strategically and efficiently, can enhance farm productivity and profitability while causing minimal environmental impact on waterways and the atmosphere. Efficient use includes applying urea at the right time and weather conditions, treating urea with urease inhibitors (UIs), or incorporating urea into soil or applying irrigation water (UNECE 2001). On irrigated lands, e.g., some parts of Canterbury in New Zealand, farmers usually irrigate after applying urea; in non-irrigated areas, farmers usually apply urea based on their anticipation of rainfall. However, applying the correct amount of irrigation soon after 
urea application is critical in minimising $\mathrm{NH}_{3}$ losses. For example, Sanz-Cobena et al. (2011) reported that addition of 7 and $14 \mathrm{~mm}$ of water to the soil immediately after urea application, reduced $\mathrm{NH}_{3}$ emission by 77 and $89 \%$, respectively; however a simulated $3 \mathrm{~mm}$ rainfall, immediately after fertilising, significantly enhanced $\mathrm{NH}_{3}$ volatilisation (with an $8 \%$ increase in emission compared to urea application without water addition). Washing urea from surface soil through irrigation water or rain water facilitates the transport of added urea to sub-surface soil layers, dilutes surface $\mathrm{NH}_{4}^{+}$ concentration, and reduces $\mathrm{NH}_{3}$ partial pressure and thereby minimise $\mathrm{NH}_{3}$ losses; however $\mathrm{NH}_{3}$ loss is exacerbated by a delay in water application by 8 to 24 hr (Black et al. 1987; Dawar et al. 2011; Sanz-Cobena et al. 2011). Therefore, the objectives of our study were to quantify $\mathrm{NH}_{3}$ emissions from pastoral systems as influenced by urea treated with nBTPT, and the timing and amount of irrigation water after urea application.

\section{Methods}

\section{Study site}

Field experiments were set up on a permanent ryegrassclover pasture managed for grazing dairy cows (3 cows $\mathrm{ha}^{-1}$ ) at Massey University Research Dairy Farm 4, Palmerston North, Manawatu, New Zealand $\left(40^{\circ} 23^{\prime} 40^{\prime \prime} \mathrm{S}, 175^{\circ} 36^{\prime} 28^{\prime \prime} \mathrm{E}\right)$ in December 2012 and January 2013. The soil is a poorly drained Tokomaru silt loam and is classified as an Argillic-fragic Perchgley Pallic Soil or Typic Fragiaqualf (Soil Survey Staff 1998) derived from deep deposits of loess-brown river sediments. The Tokomaru soil consists of a weakly to moderately developed brown silt loam A-horizon, a weakly developed grey, strongly mottled, clay loam B-horizon, and a highly compacted, weakly developed, pale gray, silt loam fragipan C-horizon that acts as a natural barrier to drainage (Hewitt 1998). Soil $\mathrm{pH}$ is 5.8, soil bulk density ranges from 1.1 to $1.3 \mathrm{~g} \mathrm{~cm}^{-3}$ and soil $\mathrm{C}$ and $\mathrm{N}$ contents range from 3.2 to $3.6 \%$ and 0.26 to $0.27 \%$, respectively.

\section{Experimental design}

The trial was laid out in a randomised block design with all treatments replicated four times (Table 1). The treatments of urea treated with $250 \mathrm{mg}$ nBTPT per $\mathrm{kg}$ of urea, and urea alone, were applied by 9 am on day 1 of urea application. Spray irrigation equivalent of 5 and $10 \mathrm{~mm}$ was applied to appropriate plots after 8,24 and $48 \mathrm{hr}$ of urea applications with or without nBTPT. Daily ammonia losses were measured over the subsequent 14 days.

\section{Gas sampling}

The active flow method described by Kissel et al. (1977) was modified to measure $\mathrm{NH}_{3}$ emission. Ammonia emission was measured by inserting a PVC chamber $\left(0.0491 \mathrm{~m}^{2}\right.$ area and $0.03 \mathrm{~m}$ height above surface soil (or $1.47 \mathrm{~L}$ volume) with two holes in the middle and a tightly sealed transparent lid to allow photosynthesis) on the perimeter of each field plot. Air from each chamber was sucked through a manifold at a constant flow rate (6 to $7 \mathrm{~L} \mathrm{~min}^{-1}$ ) using a pump, and passed through $250 \mathrm{ml}$ $0.05 \mathrm{~N}$ sulphuric acid as an ammonia trapping solution in a glass bottle. The acid solution in each bottle was replaced with fresh $0.05 \mathrm{~N} \mathrm{H}_{2} \mathrm{SO}_{4}$ solution every 24 hours and analysed for $\mathrm{NH}_{4}^{+}-\mathrm{N}$ concentration by a

Table 1 Details of the fertiliser application rate, irrigation amount and timing.

\begin{tabular}{|c|c|c|c|}
\hline \multirow[t]{2}{*}{ Fertiliser } & \multirow{2}{*}{$\begin{array}{c}\text { N rate } \\
\text { (kg N/ha) }\end{array}$} & \multicolumn{2}{|c|}{ Irrigation amount and timings after fertilisation } \\
\hline & & $(\mathrm{mm})$ & (hr after fertilisation) \\
\hline \multirow{3}{*}{ Urea } & 30 & 5 & 8 \\
\hline & & & 24 \\
\hline & & & 48 \\
\hline \multirow[t]{3}{*}{ Urea } & 30 & 10 & 8 \\
\hline & & & 24 \\
\hline & & & 48 \\
\hline \multirow[t]{3}{*}{ Urea } & 60 & 5 & 8 \\
\hline & & & 24 \\
\hline & & & 48 \\
\hline \multirow{3}{*}{ Urea } & 60 & 10 & 8 \\
\hline & & & 24 \\
\hline & & & 48 \\
\hline \multirow[t]{3}{*}{ Urea+nBTPT } & 60 & 5 & 8 \\
\hline & & & 24 \\
\hline & & & 48 \\
\hline \multirow[t]{3}{*}{ Urea+nBTPT } & 60 & 10 & 8 \\
\hline & & & 24 \\
\hline & & & 48 \\
\hline
\end{tabular}


flow injection analyser. The temperature inside each chamber was checked periodically with a thermometer. However no rise in temperature was observed during the measurement period because of continuous air suction from each chamber.

\section{Results and Discussion}

Effects of urea application rate and nBTPT on ammonia emissions

Daily $\mathrm{NH}_{3}$ emissions and cumulative $\mathrm{NH}_{3}-\mathrm{N}$ losses (measured over a 2-week period) were significantly $(\mathrm{P}<0.01)$ influenced by the $\mathrm{N}$ application rates and urease inhibitor nBTPT (Figure 1, Table 2). The largest peak of the daily $\mathrm{NH}_{3}$ emission from urea 60 and 30 $\mathrm{kg} \mathrm{N} \mathrm{ha}{ }^{-1}$ treatments appeared on day 3 following urea application, reflecting fast urea hydrolysis (Zaman et al. 2008; Dawar et al. 2011). Daily $\mathrm{NH}_{3}$ emission rates in urea treatments declined sharply after day 3 , confirming that the majority of $\mathrm{NH}_{3}$ losses occur during the first 1-3 days following urea application, depending on initial soil moisture content (Zaman et al. 2008; Dawar et al. 2011; Sanz-Cobena et al. 2011). The pattern of daily $\mathrm{NH}_{3}-\mathrm{N}$ losses from urea-nBTPT applied at 60 $\mathrm{kg} \mathrm{N} \mathrm{ha-1}$ was different from that of the urea alone treatment. Ammonia losses from urea-nBTPT applied at $60 \mathrm{~kg} \mathrm{~N} \mathrm{ha}^{-1}$ slowly increased after day 2, reached their maximum on day 5 and declined thereafter. This indicates that nBTPT partially inhibited soil urease activity, which reduced the $\mathrm{NH}_{4}^{+}$concentration in the soil solution and hence lowered the potential for $\mathrm{NH}_{3}$ volatilisation (Zaman et al. 2008).

The cumulative $\mathrm{NH}_{3}$ losses measured over a 2-week period showed that the higher urea rate $\left(60 \mathrm{~kg} \mathrm{~N} \mathrm{ha}^{-1}\right)$ resulted in 2.4 times more $\mathrm{NH}_{3}-\mathrm{N} \operatorname{loss}\left(13.2 \mathrm{~kg} \mathrm{~N}^{-1}\right)$ compared to the lower rate $\left(30 \mathrm{~kg} \mathrm{~N} \mathrm{ha}^{-1}\right)$, which lost $5.6 \mathrm{~kg} \mathrm{~N} \mathrm{ha}^{-1}$ (Table 2). The proportions of $\mathrm{NH}_{3}$ loss from applied urea were $21.8 \%$ and $18.3 \%$ of the applied $\mathrm{N}$ for 60 and $30 \mathrm{~kg} \mathrm{~N}^{-1}$ rates respectively (Table 2). A wide range of $\mathrm{NH}_{3}$ losses have been reported in the literature depending on soil physical, chemical and biological properties as well as the techniques used

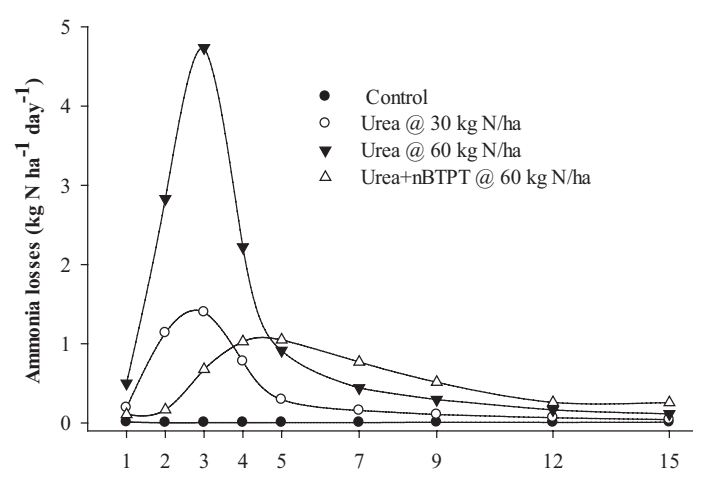

Figure 1 Daily ammonia emission as influenced by $\mathrm{N}$ rates and urea applied with urease inhibitor (nBTPT) to pasture soils. Values are means $(n=4)$.

for $\mathrm{NH}_{3}$ measurements. Black et al. (1989) compared the active method (the one used in this study) with the micrometeorological technique and reported similar $\mathrm{NH}_{3}$ losses after 9 days of $\mathrm{NH}_{3}$ measurements. The higher $\mathrm{NH}_{3}$ losses from the $60 \mathrm{~kg} \mathrm{~N}^{-1}$ rate reflect the abundant availability of substrate $\left(\mathrm{NH}_{4}^{+}\right)$, which acts as a precursor for $\mathrm{NH}_{3}$ emission, therefore frequent applications of lower $\mathrm{N}$ rates on farm could also offer potential benefit of reduced $\mathrm{NH}_{3}$ emission, but frequent application incurs additional cost for spreading fertiliser. In contrast, at the $60 \mathrm{~kg} \mathrm{~N} \mathrm{ha}^{-1}$ rate, urea + nBTPT lost only $7 \mathrm{~kg} \mathrm{~N} \mathrm{ha}^{-1}$ (11.6\% of the applied $\mathrm{N}$ ); this is a $46 \%$ lower $\mathrm{NH}_{3}$ loss than the equivalent urea alone treatment. A number of studies have reported that $\mathrm{NH}_{3}$ losses can be reduced significantly by treating urea with the urease inhibitor nBTPT (Zaman et al. 2008; Dawar et al. 2011; Soares et al. 2012). Slowing urea hydrolysis with nBTPT allows more time for urea to diffuse away from the application site or for rain or irrigation to dilute the urea and $\mathrm{NH}_{4}^{+}$concentration at the soil surface and disperse it laterally and downward in the soil, which subsequently helps retain $\mathrm{NH}_{3}$ in the soil (Dawar et al. 2011).

Table 2 Average $\mathrm{NH}_{3}-\mathrm{N}$ loss from urea and urea+nBTPT treatments, the proportion of applied $\mathrm{N}$ lost as $\mathrm{NH}_{3}-\mathrm{N}$ and percent changes during 15 days of the experiment.

\begin{tabular}{|c|c|c|c|}
\hline Treatments & $\begin{array}{c}\mathrm{NH}_{3}-\mathrm{N} \text { losses } \\
\left(\mathrm{kg} \mathrm{ha}^{-1}\right)\end{array}$ & $\begin{array}{l}\% \mathrm{~N} \text { lost as } \mathrm{NH}_{3} \\
\text { of the applied } \mathrm{N}\end{array}$ & $\begin{array}{c}\% \text { changes in } \\
\mathrm{NH}_{3} \text { relative to } \\
\text { urea alone }\end{array}$ \\
\hline No N & 0.09 & & \\
\hline Urea @ 30 kg N ha ${ }^{-1}$ & 5.58 & 18.29 & \\
\hline Urea @ 60 kg N ha-1 & 13.17 & 21.80 & \\
\hline Urea + nBTPT @ 60 kg N ha-1 & 7.07 & 11.62 & -46.7 \\
\hline standard error ("SE) & 0.47 & & \\
\hline
\end{tabular}

- indicates a reduction. ${ }^{*} \mathrm{SE}$ of the urea treatments 


\section{Effects of irrigation timing and amount on ammonia emissions}

Irrigation application time (hr) and amount (mm) had a significant effect on $\mathrm{NH}_{3}$ losses from urea alone and urea-nBTPT (Figure 2.a,b,c). The three treatments (urea applied at 30 and $60 \mathrm{~kg} \mathrm{~N} \mathrm{ha}^{-1}$ and urea $+\mathrm{nBTPT}$ at $60 \mathrm{~kg}$ $\mathrm{N} \mathrm{ha}^{-1}$ ) showed similar $\mathrm{NH}_{3}$ loss trends when the 5 and $10 \mathrm{~mm}$ of spray irrigation were applied 8, 24 or $48 \mathrm{hr}$ after urea application. Our results showed that applying 10 or $5 \mathrm{~mm}$ irrigation $8 \mathrm{hr}$ after urea application was
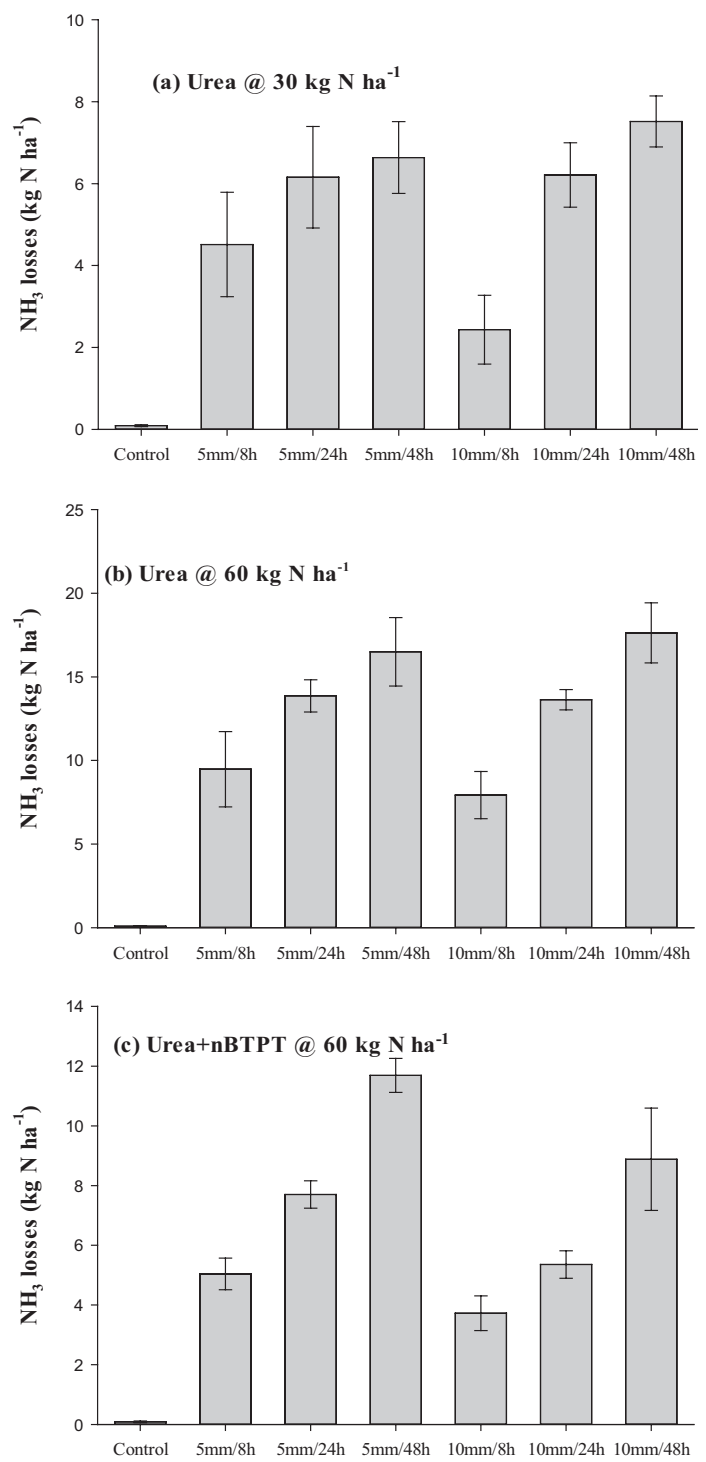

Figure 2 Ammonia emission as influenced by amount of irrigation water ( $5 \mathrm{~mm}$ and $10 \mathrm{~mm})$ and timing $(8,24$ and $48 \mathrm{hr}$ ) after urea applied at 30 and $60 \mathrm{~kg} \mathrm{~N} \mathrm{ha-}$ ${ }^{1}$ and urea-60 with nBTPT to pasture soils. Values are means $(n=4)$. Vertical bars indicate standard error (SE). Note different scales on vertical axis. more efficient at minimising $\mathrm{NH}_{3}$ losses than applying the same amount of irrigation $24 \mathrm{hr}$ after the urea was spread. Our results agree with those of Sanz-Cobena et al. (2011), who also reported that the addition of 7 and $14 \mathrm{~mm}$ of water to the soil at $61 \%$ water filled pore space (WFPS), immediately after urea spreading, reduced $\mathrm{NH}_{3}$ emission by 77 and $89 \%$, respectively. In contrast, they found that a simulated $3 \mathrm{~mm}$ rainfall to soil at 39\% WFPS, immediately after urea fertilising, significantly enhanced $\mathrm{NH}_{3}$ volatilisation (with an $8 \%$ increase in emission compared to urea application without water addition. Thus the amount of applied irrigation depends on initial soil moisture level. For example Black et al. (1987) showed that applying $4 \mathrm{~mm}$ of irrigation on to the soil at field capacity within $3 \mathrm{~h}$ of urea application resulted in significant reduction of $\mathrm{NH}_{3}$ losses. Delaying irrigation for $48 \mathrm{hr}$ further reduced its effects and resulted in even higher $\mathrm{NH}_{3}-\mathrm{N}$ losses (i.e., $25 \%$ and $29 \%$ of the applied urea- $\mathrm{N}$ at 30 and $60 \mathrm{~kg}$ $\mathrm{N} \mathrm{ha}^{-1}$, respectively). The minimal impact of 5 or 10 $\mathrm{mm}$ of irrigation applied at $24 \mathrm{hr}$ and $48 \mathrm{hr}$ highlights the fact that $\mathrm{NH}_{3}$ loss is a very quick chemical process and therefore requires early intervention. A number of studies have confirmed that the majority of $\mathrm{NH}_{3}$ loss occurs within the first 1 to 2 days after urea application (Black et al. 1985, 1987; Dawar et al. 2011; Soares et al. 2012). Therefore, the concentrations of $\mathrm{NH}_{3}$ and $\mathrm{NH}_{4}^{+}$present in the soil solution near the surface need to be diluted by applying the right amount of irrigation water to reduce its potential for volatilisation losses (Grant et al. 1996).

The decision regarding $\mathrm{N}$ fertiliser applications on farms is generally made on the availability of water from irrigation (under irrigation) or on the farmer's assessment of the likelihood of adequate rainfall arriving. Managed grassland is usually grazed every 3-4 weeks depending on the pasture growth rate, therefore urea fertiliser application is recommended at 1-5 days after rotational grazing. All paddocks are not grazed at once on farm, and urea is also not spread concurrently. Even under the most efficient irrigation system, it is practically impossible to apply irrigation water to all those paddocks soon after urea application. There will always be a lag time between urea application and the following irrigation or rainfall, suggesting that applying urea with nBTPT may have the most potential to allow more time for the urea to diffuse away from the application site after a rainfall or irrigation event (Dawar et al. 2011), and to enhance $\mathrm{N}$ use efficiency of the applied urea. Watson $e t$ al. (2008) observed that that nBTPT protects urea from degradation by the urease enzyme from 7 to 9 days. This has worldwide implications for urea use in pastoral and cropping systems, where there is a high risk of $\mathrm{NH}_{3}$ losses due to low soil moisture and high temperatures. 


\section{Recommendations}

These results have shown that there is considerable potential for improving urea fertiliser use efficiency by either treating it with $\mathrm{nBTPT}$ or applying $5-10 \mathrm{~mm}$ of irrigation soon after (less than $8 \mathrm{hr}$ ) urea application to suppress $\mathrm{NH}_{3}$ volatilisation. If the $5-10 \mathrm{~mm}$ of irrigation/rainfall is not highly likely to occur, the use of urea treated with nBTPT is strongly advised as it will considerably reduce $\mathrm{NH}_{3}$ losses. This represents a lowcost method to increase fertiliser $\mathrm{N}$ efficiency. However, the cost of the nBTPT by itself and the cost of coating it onto urea, means that urea treated with $\mathrm{nBTPT}$ will costs more than urea alone. In New Zealand grassland, nBTPT treated urea at typical application rate at $25 \mathrm{~kg}$ $\mathrm{N} /$ ha will cost $\$ 3.2 /$ ha more than applying commercial urea. However the additional cost of nBTPT-treated urea can be easily offset by taking into account the $47 \%$ reduction in $\mathrm{NH}_{3}$ losses. Using the $20 \% \mathrm{NH}_{3}$ loss as shown in this study from a typical urea application rate of $25 \mathrm{~kg} \mathrm{~N} / \mathrm{ha}$ on pastoral soil, farmers will lose about $5 \mathrm{~kg} \mathrm{~N} / \mathrm{ha}$. In contrast with this, urea $+\mathrm{nBTPT}$ (SustaiN) will conserve $2.5 \mathrm{~kg} \mathrm{~N} / \mathrm{ha}$. At a typical 10:1 $\mathrm{N}$ response, this means $25 \mathrm{~kg}$ more pasture $\mathrm{DM} / \mathrm{ha}$ from SustaiN. Assuming a conversion efficiency of $12.5 \mathrm{~kg}$ $\mathrm{DM} / \mathrm{kg}$ milk solid (MS), and a milk pay out of $\$ 7$ per $\mathrm{kg}$ MS, the value of the $2 \mathrm{~kg}$ extra milk solid will be $\$ 14$ as opposed to the cost of $\$ 3.2 /$ ha for SustaiN.

There are also associated environmental benefits, i.e., reduced $\mathrm{NH}_{3}$ losses, of using nBTPT-treated urea compared to commercial urea. An extensive review collected by Saggar et al. (2013) reported that nBTPT-treated urea applied to temperate grasslands in New Zealand can reduce $\mathrm{NH}_{3}$ emissions by $44.7 \%$. Ammonia itself is not a greenhouse gas, but can indirectly contribute to the production of $\mathrm{N}_{2} \mathrm{O}$ after land deposition. The above review suggests that the Ministry of Primary Industry (MPI) should include a specific value of 0.055 for FracGASF FNUI (fraction of urease inhibitor treated total fertiliser $\mathrm{N}$ emitted as $\mathrm{NH}_{3}$ ) in New Zealand Greenhouse Inventory, meaning lower environmental foot prints of nBTPT treated urea.

Previous claims that volatilisation of ammonia from applied urea is "insignificant" and "in the range of $0-5 \%$ of the applied N" in New Zealand conditions (Edmeades \& McBride 2012) have not been born out by this study. Combined analysis (meta-analysis) of many different trials can actually distort the facts if due attention is not paid to trial site conditions, and how well or otherwise they represent the typical range of actual farming conditions, and/or the situations in which a given product is recommended for use. Certainly, it is possible to identify conditions in advance that are less conducive to volatilisation (Stafford et al. 2008), but in the authors' considered opinion, considerably higher losses than 5\% are typical of that reported by Edmeades $\&$ McBride (2012).

\section{ACKNOWLEDGEMENTS}

We thank the technical staff of LandCare, Palmerston for their role in field and laboratory work, and Dr. Sue Page, Ballance Agri-Nutrients and Dr Bert Quin, Quin Environmental for their useful comments and feedback in the preparation of this manuscript.

\section{REFERENCES}

Barthelmie, R.J.; Pryor, S.C. 1998. Implications of ammonia emissions for fine aerosol formation and visibility impairment - a case study from the Lower Fraser Valley, British Columbia. Atmospheric Environment 32: 345-352.

Black, A.S.; Sherlock, R.R.; Cameron K.C.; Smith, N.P.; Goh, K.M. 1985. Comparison of three field methods for measuring ammonia volatilization from urea granules broadcast on to pasture. Journal of Soil Science 36: 271-280.

Black, A.S.; Sherlock, R.R.; Smith, N.P. 1987. Effects of simulated rainfall on ammonia volatilization from urea, applied to soil of varying moisture content. Journal of Soil Science 38: 679-687.

Black, A.S.; Sherlock, R.R.; Smith, N.P.; Cameron K.C. 1989. Ammonia volatilisation from urea broadcast in spring to autumn-sown wheat. New Zealand Journal of Crop and Horticultural Science 17:175-182.

Dawar, K.; Zaman, M.; Rowarth, J.S.; Blennerhassett, J.D.; Turnbull, M.H. 2011. Urea hydrolysis and lateral and vertical movement in the soil: effects of urease inhibitor and irrigation. Biology and Fertility of Soils 47: 139-146.

Edmeades, D.C.; McBride, R.M. 2012. Evaluating the agronomic effectiveness of fertiliser products. Proceedings of the New Zealand Grassland Association 74: 217-224.

Grant, C.A.; Jia, S.; Brown, K.R.; Bailey, L.D. 1996. Volatile losses of $\mathrm{NH}_{3}$ from surface applied urea and urea ammonium nitrate with and without the urease inhibitors NBPT or ammonium thiosulphate. Canadian Journal of Soil Science: 417-419.

Hewitt, A.E. 1998. New Zealand Soil classification. 2nd ed. Lincoln, New Zealand, Manaaki Whenua Press.

Kissel, D.E.; Brewer, H.L.; Arkin, G.F. 1977. Design and test of a field sampler for ammonia volatilization. Soil Science Society of America Journal 41: 1133-1138.

Ledgard, S.F.; Penno, J.W.; Spronsen, M.S. 1999. Nitrogen inputs and losses from clover/ryegrass pastures grazed by dairy cows, as affected by nitrogen fertilizer application. Journal of Agricultural Science Cambridge 132: 215-225.

Saggar, S.; Singh, J.; Giltrap, D.L.; Zaman, M.; Luo, 
J.; Rollo, M.; Kim, D.G.; Rys, G.; van der, Weerden, T.J. 2013. Quantification of reductions in ammonia emissions from fertiliser urea and animal urine in grazed pastures with urease inhibitors for agriculture inventory: New Zealand as a case study. Science of the Total Environment. http://dx.doi.org/10.1016/j. scitotenv.2012.07.088.

Sanz-Cobena, A.; Misselbrook, T.; Camp, V.; Vallejo, A. 2011. Effect of water addition and the urease inhibitor NBPT on the abatement of ammonia emission from surface applied urea. Atmospheric Environment 45: 1517-1524.

Soares, J.R.; Cantarella, H.; Menegale, M.L.C. 2012. Ammonia volatilization losses of surface applied urea with urease and nitrification inhibitors. Soil Biology and Biochemistry 52: 82-89.

Soil Survey Staff 1998. Keys to soil taxonomy (8th ed.), United States Department of Agriculture, Washington, DC.

Stafford, A.; Catto, W.; Morton, J.D. 2008. Ballance Agri-Nutrients approach to sustainable fertiliser use. Fertiliser and Lime Research Center, Massey University, Occasional Report No. 21: 197-205.

Statistics New Zealand 2012. Agricultural Production Census (Provisional Results) December 2012: Commentary. Wellington, Statistics New Zealand.
UNECE. 2001. UNECE framework code for Good Agricultural 542 Practices for reducing ammonia. Expert Group on Ammonia Abatement. Geneva, United Nations Economic Commission for Europe. http://www.clrtaptfrn.org/sites/clrtaptfrn.org/files/ documents/EPMAN\%20Documents/eb.air.wg.5.200

Watson, C.J.; Akhonzada, N.A.; Hamilton, J.T.G.; Matthews, D.I. 2008: Rate and mode of application of the urease inhibitor N-n-butyl thiophosphoric triamide on ammonia volatilization from surfaceapplied urea. Soil Use Management 24: 246-253.

Zaman, M.; Cameron, K.C.; Di, H.J.; Noonan, M.J. 1998. Nitrogen mineralisation rates from soil amended with dairy pond waste. Australian Journal of Soil Research 36: 217-230.

Zaman, M.; Nguyen, M.L.; Blennerhassett, J.D.; Quin, B.F. 2008. Reducing $\mathrm{NH}_{3}, \mathrm{~N}_{2} \mathrm{O}$ and $\mathrm{NO}_{3}^{-}-\mathrm{N}$ losses from a pasture soil with urease or nitrification inhibitors and elemental S-amended nitrogenous fertilizers. Biology and Fertility of Soils 44: 693-705. Zaman, M.; Zaman, S.; Adhinarayanan, C.; Nguyen, M.L.; Nawaz, S.; Dawar, K.M. 2013. Effects of urease and nitrification inhibitors on the efficient use of urea for pastoral systems. Soil Science and Plant Nutrition. http://dx.doi.org/10.1080/00380768.2013.812940 